\title{
Kazimierz Pułaski alias Casimir Pulaski and His Memorial Trajectory in the Eighteenth-Century American Press
}

Kazimierz Pułaski, known in the United States under the anglicized name of Casimir Pulaski, is celebrated today as "the hero of two nations", "the knight of freedom" and "the father of the American cavalry" with a permanent place in the Pantheon of Revolutionary Generals. ${ }^{1}$ Numerous material, performative and symbolic displays of Pulaski's special status in his native Poland and in the American Republic he died for amply illustrate this prominent position: the celebration of General Pulaski Memorial Day with a large parade in NYC on 11 October of each year since 1929; the Casimir Pulaski Day in Illinois observed on the first Monday of each March since 1977; hundreds of monuments, busts and memorial plaques, including his first statue dedicated in Savannah, Georgia, in 1855; several cities and counties, countless streets, parks, schools, organizations, foundations and cultural institutions named after him; the Casimir Pulaski Museum in Warka, Poland, opened in 1967, and the most recent rare distinction of conferring honorary U.S. citizenship on Pulaski by the US Congress in 2009. These and other national and local commemorative markers of Pulaski's presence in the public space and historical imagination of both Poles and Americans have been appearing parallel to the scholarly efforts of discovering, analyzing and presenting the historical facts of his life and military career. The rich and diverse historiography of Casimir Pulaski on both sides of the Atlantic may justly challenge the need for and novelty of one more historical study devoted to him.

However, recent theoretical, methodological and empirical advances affecting the discipline of history - cultural history in particular - justify the present attempt at examining the early stages of Pulaski's "career" as an overseas hero of the American Revolution. The first such development providing a fresh perspective and new conceptual tools is the emergence and dynamic development of

\footnotetext{
1 Work on this article was supported by the grant from the National Science Centre Poland (NCN) no. 2015/19/B/HS3/01941.
} 
Memory Studies, a cross-disciplinary field dealing with "the social, cultural, cognitive, political and technological shifts affecting how, what and why individuals, groups and societies remember, and forget." ${ }^{2}$ History's turn to the study of mnemonic processes in the past and the incorporation of the term into its disciplinary terminology has produced many original research insights and enabled the study of new lines of inquiry. ${ }^{3}$ The second development, not so very recent anymore, is the acceptance and widespread use of newspapers and magazines as legitimate sources in historical and cultural studies, also of eighteenth-century Europe and America. ${ }^{4}$ Despite the accepted problems with their validity and reliability, a range of research strategies have been worked out and perfected to make the best use of them. ${ }^{5}$ Moreover, collating into a single database various once-dispersed historical sources, accompanied by the improvement of search engines, have made these sources more accessible, readable, searchable and downloadable. Without ignoring the epistemological hazards of doing digital history, its practitioners and cautious observers agree that digital archives do open up new lines of historical research, once too costly, time-consuming and unmanageable for single scholars. ${ }^{6}$ Using the

\footnotetext{
2 From the description of the Memory Studies journal, https://us.sagepub.com/en-us/nam/journal/ memory-studies\#description. For a useful discussion of the emerging field see Henry L. Roediger, James V. Wertsch, Creating a new discipline of memory studies, "Memory Studies" 2008, vol. 1 (1), pp. 9-22.
}

3 For studies on the relation between memory and history see BożenaKrzywobłocka, "Prasa jako źródło historyczne", [in:] Mieczysław Kafel, ed., Metody i techniki badawcze w prasoznawstwie, t. 3, Warszawa 1971, pp. 60-80; Amos Funkenstein, Collective Memory and Historical Consciousness, "History and Memory" 1989, vol. 1 (1), pp. 5-26; David Thelen, Memory and American History, "Journal of American History", 1989, vol. 75 (4), pp. 1117-1129; Marie-Noëlle Bourguet, Lucette Valensi, Nathan Wachtel, eds., Between Memory and History, Chur, London and Paris, 1990; Jenéa Tallentire, Strategies of Memory: History, Social Memory, and the Community, "Histoire Sociale/ Social History” 2001, vol. 34 (67), pp. 197-212; Geoffrey Cubitt, History and Memory, Manchester, 2007; Karolina Polasik-Wrzosek, Pamięć kulturowa a historiografia. Konteksty do zbadania, "Historyka” 2011, vol. XLI, pp. 137-144.

4 Adam Kersten, W sparwie badań nad poczatkami prasy polskiej, "Kwartalnik Historyczny"1963, vol. 1, pp. 69-83; Michael Harris and Alan Lee, eds., The Press in English Society from the Seventeenth to Nineteenth Centuries, Vancouver, 1986; Richard D. Brown, Knowledge is Power: The Diffusion of Information in Early America, 1700-1865, Oxford and New York, 1989; Charles E. Clark, The Public Prints: The Newspaper in Anglo-American Culture 1665-1740, New York and Oxford, 1994; Władysław Marek Kolasa, Historiografia prasy polskiej (do 1918 roku), Kraków, 2013 .

5 Joseph Baumgartner, Newspapers as Historical Sources, "Philippine Quarterly of Culture and Society” 1989, vol. 9, pp. 256-258; Roberto Franzosi, The Press as a Source of Socio-Historical Data: Issues in the Methodology of Data Collection from Newspapers, "Historical Methods" 1987, vol. 20 (1), pp. 5-16; Robert B. Allen and Robert Sieczkiewicz, How Historians use Historical Newspapers, "Proceedings of the American Society for Information Science and Technology" 2001, vol. 47.

6 Daniel Cohen and Roy Rosenzweig, "Introduction", Digital History: A Guide to Gathering, Preserving, and Presenting the Past on the Web, Philadelphia, 2005, pp. 1-17. 
perspectives, insights and tools of these academic and technological advancements, this study is an attempt at tracing and interpreting the earliest stages of Casimir Pulaski's meandering road to prominence in American national memory as reflected in the American press of the Revolutionary and Early Republican periods.

Modern scholarly preoccupation with the human processes of remembering and forgetting go back to such early $20^{\text {th }}$-century theorists as Emile Durkheim, Sigmund Freud, Maurice Halbwachs, Marc Bloch and Evans-Pritchard, ${ }^{7}$ whose reflection was developed by younger generation thinkers such as Paul Ricoeur, Pierre Nora and Jan Assmann. ${ }^{8}$ In today's Memory Studies a great deal of attention is still devoted to the typology of memory and the refinement of its definition. Sociologists, psychologists and historians debate the concepts of individual, collective, social, community, cultural and national memory, analyse their multiple forms and intricate interrelationships. While it is beyond the scope of this essay to address the nuanced theoretical issues of memory, a working definition of American national memory was adopted here for the studied period as a particular use of social memory by the dispersed colonial communities in search of a shared identity as members of the independent state they struggled and eventually succeeded in creating in 1783.

In their interdisciplinary work on social memory, Fentress and Wickham agree with Halbwachs that various group versions of the past "are established by communication, not by private remembrance." ${ }^{\prime 9}$ The statement is important for validating the archival sources for the present study that consist of a selection of extant American newspapers published in the years 1777-1815. The historical newspapers are treated here as channels of social communication: as sources of news, i.e. factual information about past events and persons, and as public memory sites in which certain narratives about them were produced and circulated. It is important to remember that the press in early America was the only relatively well-developed form of mass communication. Clark claims that newspapers in $18^{\text {th }}$-century British colonial America, apart from providing a mixture of news from the Metropolis, the European continent, the neighboring American provinces and their own localities, played an important role in narrowing "the cultural gap between the learned and the merely literate." ${ }^{10} \mathrm{He}$ argues about their broader demographic and social

\footnotetext{
7 Jeffrey K. Olick and Joyce Robbins, Social Memory Studies: From "Collective Memory" to the Historical Sociology of Mnemonic Practices, "Annual Review of Sociology” 1998, vol. 24, pp. 105-140.

8 Maurice Halbwachs, On Collective Memory (transl. by L. A. Coser), Chicago 1992; Paul Ricoeur, Memory, History, Forgetting (transl. by K. Blamey and D. Pellauer), Chicago 2004; Jan Assmann, Cultural Memory and Early Civilization: Writing, Remembrance, and Political Imagination, Cambridge 2011.
}

9 James Fentress and Chris Wickham, Social Memory, Cambridge, Mass., 1992, p. x.

10 Charles E. Clark, op. cit., pp. 251-257 
readership than the narrow socio-economic elites, a point supported by Brown's own and quoted data on the proliferation of local newspapers in port and state capital towns between the 1790s and 1820s and their role in the social diffusion of information. ${ }^{11}$ Clark's opinion that "by combining materials from all walks and levels of life" the newspapers of the time reflected the collective mentality of their communities and participated in giving coherence to provincial culture ${ }^{12}$ further supports the premise that those printed texts can be productively explored both as historical "sites" and sites of American social memory. ${ }^{13}$

A number of existing works on Casimir Pulaski constitute a rich historiographic background to this study. Older and more recent biographical classics intended for academic, specialist and general readers, based on solid research of state documents, maps, private and official correspondence, family papers etc., provide ample factual information about Pulaski in all periods of his eventful life. ${ }^{14}$ Collections of essays in Polish and English published in recent decades also demonstrate the presence of Pulaski as a theme in Polish and American works of literature, art, music and material culture. ${ }^{15}$ Yet nobody has looked systematically at what was written about Pulaski in the American press of the Revolutionary and post-Revolutionary period. Attempting to fill this lacuna, the present study contributes new knowledge about the life and afterlife of Pulaski in Early America as represented by its media.

The online resource for this project is America's Historical Newspapers digitized and offered by the Readex database, specifically the part called Early American Newspapers, Series 1, 1690-1876. The series includes more than 730 American newspapers and offers essential titles from 23 states/colonies and the District

\footnotetext{
11 Richard D. Brown, op. cit., pp. 111, 218, 347 n.1.

12 Clark, op. cit., p. 257.
}

13 See the distinction between memory sites and memory carriers by Andrzej Szpociński, Nośniki pamięci, miejsca pamięci, "Sensus Historiae" 2014, vol. 17 (4), pp. 17-26.

14 Władysław Konopczyński, Kazimierz Pułaski: życiorys, Kraków 1931; Antoni Lenkiewicz: Kazimierz Pułaski (1745-1779), Wrocław 2004; Leszek Szymanski, Casimir Pulaski: A Hero of the American Revolution, New York 1979/1994; Francis Casimir Kajencki, Casimir Pulaski: Cavalry Commander of the American Revolution, El Paso, 2001; Jolanta Daszyńska, "Droga Pułaskiego do Savannah", [in:] Czas Ameryki. American Era. Ksiega ku czci Profesora dr. hab. Krzysztofa Michały $k a$, red. H. Parafianowicz, Białystok 2011, ss. 27-44.

15 Iwona Stefaniak, ed., 40 lat Muzeum im. Kazimierza Pułaskiego w Warce. Bohater, historia i perspektywy rozwoju. Materiały z polsko-amerykańskiego sympozjum w Warce-Winiarach, 1316 października 2007r./ Forty years of the Casimir Pulaski Museum in Warka. The hero, history and perspectives for development. Papers from the Polish-American symposium in Warka-Winiary, October, 13-16, Warka 2007; Iwona Stefaniak, Karol Kucharski, eds., Kazimierz Pułaski w 230. rocznicę śmierci. Materiały z sesji naukowej zorganizowanej 7 grudnia 2009 r. w Muzeum Niepodr leglości w Warszawie, Warka, 2011; Dariusz Kupisz, Andrzej Pytlak, eds., Kazimierz Pułaski i jego czasy w historii, literaturze, kulturze. W 270 rocznicę urodzin, Warka 2016. 
of Columbia. Another database searched for the project, not available through Readex, was the collection of the Virginia Gazette accessed from the Digital History Center at the Colonial Williamsburg Foundation's Research Division. The examined period starts in the year 1777, Pulaski's arrival to America, and stops in 1815, the end of the War of 1812, known as the second war of American independence. The war became an important turning point in the history of the young republic. By accelerating the appropriation of Indian lands for white settlement and the expansion of slavery, it promoted national self-confidence, helped Americans define who they were and where their country was heading. It also produced its share of heroes, such as Andrew Jackson, John Quincy Adams and James Monroe. ${ }^{16}$ In a way it was a delayed completion of the state formation processes started by the American Revolution.

The most often mentioned value of historical newspapers is that sometimes they are the only available source accessible to a historian, that their reports are close in time to the narrated events, often made by the people directly involved in or witnessing them. The most serious defects of newspaper data, on the other hand, are their validity (reporting bias, selectivity, tendency to report sensational and negative news, downplaying certain aspects of events, etc.) and reliability (factual errors in the reports, faulty information not corrected in subsequent editions). ${ }^{17}$ When dealing with newspapers of a remote period, other factors influence their usefulness as historical sources: the number of surviving issues, their physical condition and legibility as well as the irregular methods of news gathering (oral reports of witnesses, reprints from other papers - often with considerable delay, fragments of private letters etc.). Nevertheless, the important advantage is that the news reports concerning the War of Independence are the product of genuine American journalism for American readers, in contrast to extensive reprints from English newspapers, ubiquitous in colonial times when printers operated under the strong influence of the journalistic and metropolitan intellectual and literary fashions of contemporary England. The recognition of this fact additionally strengthens their status as both a locus and a carrier of American collective memory. By treating them as such, I do not look in them for new or forgotten facts about Pulaski in America nor attempt to correct historical errors they may contain, but attempt to show his media evolution from a temporary war news item into a lasting component of a conscious effort to recall the revolutionary war as narratives on the nation's heroic deeds.

The performed analysis started with selecting from the long list of digitized newspapers the titles that operated in the period of Pulaski's physical presence in

16 Donald R. Hickey, The War of 1812: A Forgotten Conflict, Bicentennial Edition, Urbana 2012; Interchange: The War of 2012, "Journal of American History" 2012, vol. 99 (2), pp. 520-555.

17 After Franzosi, op. cit., pp. 5-7. 
America, i.e. between July 1777 (his arrival at Marblehead Harbor in Massachusetts) and October 1779, the month of his death from gangrene on board the Wasp, the hospital ship heading for Charleston. Twenty nine such newspapers have been identified, only six of which reported Pulaski in some form: five of them only once and one - The Virginia Gazette - as many as twelve times; three titles were loyalist (nos. 19, 20 and 24). The results are shown in the table below.

\begin{tabular}{|l|l|l|l|}
\hline No. & Newspaper title & Place of publication & Pulaski reported \\
\hline 1 & Connecticut Courant & Hartford, CT & \\
\hline 2 & Connecticut Journal & New Haven, CT & \\
\hline 3 & Connecticut Gazette & New London, CT & 1 x (July 1779) \\
\hline 4 & New-London Summary & New London, CT & \\
\hline 5 & Norwich Packet & Norwich, CT & \\
\hline 6 & Georgia Gazette & Savannah, GA & \\
\hline 7 & Boston Gazette & Boston, MA & \\
\hline 8 & $\begin{array}{l}\text { Continental Journal and Weekly } \\
\text { Advertiser }\end{array}$ & Boston, MA & 1 x (Nov. 1778)* \\
\hline 9 & Independent Chronicle & Boston, MA & \\
\hline 10 & Independent Ledger & Boston, MA & \\
\hline 11 & Essex Journal & Newburyport, MA & \\
\hline 12 & Massachusetts Spy & Worcester, MA & \\
\hline 13 & New- Jersey Gazette & Burlington, NJ & \\
\hline 14 & New-Jersey Gazette & Trenton, NJ & $1 \mathrm{x}($ October 1778)* \\
\hline 15 & Freeman's Journal & Portsmouth, NH & \\
\hline 16 & New Hampshire Gazette & Portsmouth, NH & \\
\hline 17 & $\begin{array}{l}\text { New York Gazette, and Weekly } \\
\text { Merkury }\end{array}$ & New York, NY & \\
\hline 18 & New-York Journal & New York, NY & \\
\hline 19 & Rivington's New York Loyal Gazette & New York, NY & \\
\hline 20 & Royal Gazette & New York, NY & \\
\hline 21 & Pennsylvania Packet & Philadelphia, PA & $2 \times$ (Sept. 1778 and \\
\hline 22 & Pennsylvania Evening Post 1778$)$ \\
\hline & Philadelphia, PA & \\
\hline
\end{tabular}




\begin{tabular}{|l|l|l|l|}
\hline No. & Newspaper title & Place of publication & Pulaski reported \\
\hline 23 & $\begin{array}{l}\text { Pennsylvania Ledger: or the Virgi- } \\
\text { nia, Maryland, Pennsylvania, and } \\
\text { New-Jersey Weekly Advertiser }\end{array}$ & Philadelphia, PA & \\
\hline 24 & $\begin{array}{l}\text { Royal Pennsylvania Gazette } \\
\text { (loyalist) }\end{array}$ & Philadelphia, PA & 1 x (May 1778) \\
\hline 25 & Wochentliche & Philadelphia, PA & \\
\hline 26 & Newport Mercury & Newport, RI & \\
\hline 27 & $\begin{array}{l}\text { American Journal and General } \\
\text { Advertiser }\end{array}$ & Providence, RI & \\
\hline 28 & Providence Gazette & Providence, RI & \\
\hline 29 & Virginia Gazette & Williamsburg, VA & $12 \mathrm{x}$ \\
\hline
\end{tabular}

*identical reports

Chronologically the earliest mention of Pulaski in the extracted corpus occurred in The Virginia Gazette of 26 Dec. 1777, in the reprinted fragment of a letter "from an officer at camp, dated Dec. 16" received from Baltimore. Judging by the dates, places and names of the commanding officers mentioned in it, the text reports the Battle of White Marsh fought on 5-8 December 1777 in the area of Whitemarsh Township, Pennsylvania. The battle, which took the form of a series of skirmish actions, was the last major engagement in that year between British and American forces, after which the Continental Army retreated to Valley Forge. The extract reads as follows:

"On the $8^{\text {th }}$ the enemy remained in position, and under cover of their usual stratagem, leaving great fires on their ground, decamped in the evening. It was doubted at first whether they meant to retreat, or whether they were only filing off in order to prepare for an attack on our right. Count Pulaski with a party of horse, and a few infantry which he had collected, followed them watching their motions. As soon as the real design of the enemy was ascertained, light parties were ordered to pursue, and a larger body to support them; but the enemy's march was too rapid to allow of their being overtaken by any other than Count Pulaski's party, who, with his handful of men, made an attack upon their rear guard." 18

\footnotetext{
18 Dixon and Hunter, p. 1. In this and all other quotations from the historical newspapers, I have retained the original spelling, capitalization and punctuation. Quotes from The Virginia Gazette are additionally provided with the names of the newspaper printers, as it appeared from different printers in Williamsburg.
} 
The subsequent reports of different length and nature sketch out Pulaski's career in America, his movements, military engagements and their results. The Royal Pennsylvania Gazette mentioned "Count Pulaski" as brigadier on its list of "General officers now serving in the rebel army", thus confirming his high rank in the Continental Army. ${ }^{19}$ Another report, rather like a wanted notice, informed about a deserter from Pulaski's legion and about a reward for bringing him to the commander's quarters. ${ }^{20}$ In this way it also confirmed the existence of Pulaski's Cavalry Legion, the formation of which earlier that year was not recorded in any of the papers in the database. Pulaski's letter to the President of the Continental Congress of 16 October 1778 reprinted in the Pennsylvania Packet reports the Legion's losses at Little Egg Harbor in southern New Jersey on the previous day, which he estimated as "dead, wounded and absent, about 25 or 30 men, and some horses". ${ }^{21}$ After that engagement, Pulaski and his legion returned to Trenton, as stated by a local paper and subsequently reprinted in Boston. ${ }^{22}$

After that the newspapers went silent about Pulaski for three months, a period coinciding with the winter rest of the Continental Army at Valley Forge, whereupon a series of shorter and longer reports started appearing, mainly in The Virginia Gazette, and showed him operating in South Carolina near Charleston. The issue of the paper of 19 February 1779 contains information "that Count Pulaski with his legion, was on their march to the southward, to join General Lincoln." ${ }^{23}$ In an April issue, the Gazette reported in the Williamsburg news section that " This day arrived in town, Count Pulaski, with his retinue $\&$ c. on their way to the southward." ${ }^{24}$ Two months later, in June, the same paper placed delayed news obtained from South Carolina about a military engagement of Pulaski's legion near Charleston informing that "Count Pulaski has had a smart skirmish, in which his horse was killed under him with fourteen balls, the Count himself not hurt, but that several officers of his corps were killed..." ${ }^{25}$ Around that time the news about the South Carolina campaign reached the northern states and the Connecticut Gazette reprinted an extract from a letter of June 10 obtained from Virginia saying that "General Pulaski, at the head of the legion, had reached Charlestown, a few days before the enemy, and issuing forth immediately, took 180 of their advanced guard." ${ }^{26}$ Two more

\footnotetext{
May 19, 1778, p. 3.

20 The Pennsylvania Packet, Sept. 29, 1778, p. 1.

2120 October 1778, p. 2.

22 The New Jersey Gazette, Oct. 28, 1778, p. 3; The Continental Journal, and Weekly Advertiser, November 12, 1778, p. 3.

23 Dixon and Nicolson, Feb. 19, 1779, p. 3.

24 Dixon and Nicolson, April 16, 1779, p. 2.

25 Ibidem, June 12, 1779, p.2.

26 The Connecticut Gazette; and the Universal Intelligencer, July 8, 1779, p. 2.
} 
Virginia Gazettes, both of October 1779, contain glimpses of Pulaski's activities during the siege of Savannah, Georgia, a joint Franco-American attempt to retake the city controlled by the British that lasted from 16 September to 18 October 1779. One report reads that while Major General Lincoln was approaching Savannah to join forces with the French admiral comte d'Estaing, "General Count Pulaski had already taken a Picket of the enemy..."27. Information about the same operation was repeated by the Gazette about two weeks later after a different source and read that "the active and enterprising General Count Pulaski with the cavalry had to thoroughly cleared ( $\mathrm{sic}$ ) the way, and broke up the enemy's advanced posts." ${ }^{28}$ On 20 November 1779, Pulaski's name appeared in two different editions of the Gazette, but only the entry in Dixon and Nicolson is legible. In a report on the failed attempt to re-capture Savannah from the British based on the account of a Major Clarkson, who stopped in Williamsburg on his way to Philadelphia with dispatches from General Lincoln to the Congress, the readers were informed that:

After an arduous bloody conflict of four hours and six minutes, during which the Count D'Estaing was wounded slightly in his leg, and arm, General Pulaski mortally wounded, Majors Morte and Wise, of Carolina, killed, and several other officers of both columns and about 500 privates killed and wounded (...) The brave Count Pulaski died of his wounds on the $13^{\text {th }}$ of October and his corpse was carried to Charlestown and there interred with great military funeral pomp and with every other mark of respect that a generous and grateful people could show a hero who had sacrificed his life in defence of their liberties. ${ }^{29}$

A similar piece of news dated 30 October appeared in the Gazette two weeks later as a part of the list of American casualties during the siege of Savannah:

The gallant Count Pulaski died at sea, on his return from Georgia, of his wounds and on Thursday last his funeral rites were performed here, in a manner suitable to the rank and merits of this intrepid and much lamented officer. ${ }^{30}$

Despite the irregular and fragmentary nature of the newspaper reports on $\mathrm{Pu}-$ laski in the time of his operation in America, they demonstrate visible discursive similarity. The insights provided by today's research on the English language in the news, although not all applicable to the newspapers of revolutionary America, help notice certain linguistic characteristics of those early journalistic texts. ${ }^{31}$ Firstly, Pulaski's name is always premodified by the noun Count or the noun phrase

\footnotetext{
27 Dixon and Nicolson, Oct. 9, 1779, p.2.

28 Ibidem, Oct. 23, 1779, p. 2.

29 Dixon and Nicolson, Nov. 20, 1779, p.2.

30 Ibidem, Dec. 4, 1779, p. 2.

31 See Roger Fowler, Language in the News: Discourse and Ideology $n$ the Press, London and New York 1991, chap. 5; Monika Bednarek and Helen Caple, News Discourse, London 2012, pp. 84-90.
} 
General Count. The attributive adjectives characterizing Pulaski - smart, gallant, intrepid, active, enterprising - represent him positively as brave and energetic. This image is additionally reinforced by prevalent active verbs of a military lexical register employed in describing Pulaski's actions: made an attack; driven the enemy on board their vessels; took 1800 of their [British] advanced guard; was on march to the southward; had a smart skirmish; had taken a picket of the enemy; broke up the enemy's advanced posts. His foreign origin and adventurous political life in his native Poland were never mentioned; instead, he was presented to American readers as operating on their territory, participating in their war hand in hand with their countrymen. This cultural proximity of Pulaski is construed in the news report by references to American places, such as Egg Harbour, Trenton, Charlestown, Savannah, South Carolina, Georgia, and his American comrades-in-arms: George Washington, Gen. Moultrie and Major General Lincoln. Thus, the overall image of Pulaski circulated by means of such narratives was that of a prominent member of European aristocratic elites (although in fact he merely belonged to the Polish landed gentry), a high-ranking officer in the Continental Army and a commander of unusual fighting skills and rare courage who endeared himself to the Americans by joining their struggle and sacrificing his life for their independence.

By the time of Pulaski's death of wounds incurred in combat, ostensibly the ground was prepared by the press for his afterlife in the social consciousness and memory of Americans as their hero. However, contrary to expectations, Pulaski disappeared completely from the pages of the American press after 1779 for fourteen long years. His name reappeared on 20 December 1793 on the front page of the Gazette of the United States and Evening Advertiser and was located in no more than sixteen other newspapers between 1793 and 1815. Both the return of Casimir Pulaski to the press pages after a long time break and the new social contexts and practices involving his person evidenced by the reports and advertisements deserve closer attention.

The "newsbites" on Pulaski during the War of Independence were replaced in the newspapers of the early American Republic by narratives and pieces of information indicative of the process of his mythologization in American culture. Three forms of the Pulaski myth formation have been distinguished in the press of 1793-1815. The first one is eponymy, i.e. naming objects and places after Pulaski. A short report of a sea incident found in a local Providence paper of May 1795 reveals that a battleship was named after him:

...off Charleston Bar, an Action took place between the French privateer Brig General Pulaski, mounting 16 six pounder and a Bermudian privateer ship, Sir Charles Grey, mounting 18 Twelves and 2 six pounders... ${ }^{32}$

32 The Amherst Journal and the New-Hampshire Advertiser, May 1, 1795, p. 63. 
In 1814 either the same Pulaski was still in operation, or another one received his name, judging by a piece of news repeated in the Massachusetts and New Jersey papers:

The price mentioned as being on shore near Georgetown, proves to be the British brig Roper, from Malta bound to London, with the cargo of sweet oil, captured by the privateer Pulaski, of Baltimore. ${ }^{33}$

Elsewhere, Pulaski's name was given to a stallion, as appears from the Connecticut paper Norwich Courier, which carried the following advertisement placed by Joseph Brewster:

The English horse Count Pulaski, will be let to mares this season at the stable of the subscriber in Norwich. (...) Pulaski is one of the surest foal getters in this state, and his flock allowed by the best judges to be very fine. ${ }^{34}$

In Kentucky, a newly created county was named Pulaski by the decision of the state legislators, as announced by the Federal Gazette \& Baltimore Daily Advertiser of 28 March 1799. It turned out to be the first of other Pulaski counties subsequently created in six other states in the first half of the nineteenth century.

The second process in Pulaski's myth formation identified in the study material was fictionalization, i.e. his appearance as a character of literary and semi-literary texts. One such example is a story published on the front page of the Gazette of the United States and Evening Advertiser and introduced as "an interesting account of the attempt to assassinate the King of Poland, in 1771, for which Count Pulaski was obliged to flee from his country". ${ }^{35}$ It is followed by a two-column account of the attempt to kidnap and assassinate the Polish king Stanisław August in 1771 by a group of Bar confederates led by "a Polish Nobleman named Pulaski, a general in the army of the confederates, who planned the atrocious enterprise". The whole sensational account, with a remarkable amount of detail, is marked by a tone of indignation at the impudence and daring of Pulaski and his companions. The story is continued by the same paper three days later. After reporting the capital punishment of Pulaski's two closest companions for the attempted regicide, the text ends with the information that:

After the conclusion of the troubles, Pulaski escaped from Poland, and repaired to America: he distinguished himself in the American Service, and was killed in forcing the British lines at the siege of Savannah in 1779. ${ }^{36}$

\footnotetext{
33 New-Jersey Journal, Nov. 22, 1814, p. 3; The Repertory, November 22, 1814, p. 4; Salem Gazette, Nov. 22, 1814, p. 3.

34 July 12,1798 , p. 4.

35 Dec. 20, 1793, p. 1.

36 Dec. 23, 179 3, p. 1.
} 
In February 1797, the Philadelphia Minerva printed the first part of "The interesting history of the Baron de Lovzinski. With a relation of the most remarkable occurrences in the life of the celebrated Count Pulaski, well known as the champion of American liberty, and who bravely fell in its defence before Savannah, 1779. Interspersed with anecdotes about the late unfortunate King of Poland." ${ }^{37}$ The author was Jean-Baptiste Louvet de Couvray (1760-1797), a French novelist, playwright, journalist and diplomat, who in his story originally entitled Les Amours $d u$ chevalier de Faublas, partly set in Poland and full of factual inaccuracies ${ }^{38}$, thus characterized Pulaski:

Celebrated for the austerity of his manners, famous on account of the unflexibility of his virtues, which were truly republican, Pulaski, at once a great captain and a brave soldier, had more than one occasion signalized his fiery courage, and his ardent patriotism. ${ }^{39}$

A continuation of the story appeared a year later in the Chelsea Courier, and in this part Pulaski features mainly as a commander of Polish troops fighting against the Russians in Poland. ${ }^{40}$ His name appeared again in the advertisement of the same book in the Salem Gazette as a factor enhancing its attraction by promising "many surprising incidents in the life of the late Count Pulaski." 41

Thanks to the "Literary Bouquet" section of the New Jersey Journal we know that an anonymous poet was inspired by the figure of Pulaski to compose a poem in his honour entitled "Stanzas in memory of Count Pulaski". A few selected verses illustrate its apotheosizing tone:

Columbia's clarion, with awaking tone call'd the brave chief to shield her injur'd land (...)

And horsemen quivered at Pulaski's passing shade ${ }^{42}$

The third and probably the most interesting process was making Pulaski an element of the young nation's foundation mythology by assigning him a place in the pantheon of the revolutionary heroes as well as using his person in contemporary situations of social conflict to make a political statement. A good case in point is a lengthy report on the celebration of twenty years of American independence at

\footnotetext{
37 Feb. 4, 1797, p.1.
}

38 For a critical plot summary see Andrzej Pytla, "Mit Pułaskiego w operze francuskiej doby Ree wolucji: Lodoïska Luigiego Cherubiniego i Lodoïska Rodolphe'a Kreutzera”, in: D. Kupisz, A. Pytlak, eds, Kazimierz Pułaski i jego czasy, op. cit, pp. 95-98.

\footnotetext{
39 Feb. 4, 1797, p. 1.

40 March 1, 1798, pp. 1-2.

41 April 5, 1799, p. 3.

42 June 22, 1796, p. 4
} 
Princeton College in 1796. It contains the full text of a grandiloquent oration delivered by a Mr. Forsyth, who evoked Pulaski in this lofty way:

If on this day we may mingle the tears with the triumphs of patriotism, let us first bedew with some sacred drops, the urns of Warren, of Montgomery, of Herkimer, of Mercer, of De Kalb, and Pulaski. Glorious men! Through fields of fire you have pursued your way to immortal renown. On the altars of liberty you have offered your own lives as victims for the public safety." ${ }^{43}$

Another report on the patriotic celebration on the $4^{\text {th }}$ of July 1812 at the Republican Military School at Fishing Creek in South Carolina informed that, after the formal part, several toasts were drank "with the laud peals of applause." Toast no. 11 paid tribute to "the memory of De Kalb, Pulaski, and all strangers who died for our independence - may they ever be held in veneration." 44

The Polish origin of Pulaski became important in the 1800s in connection with the protests of foreign-born naturalized citizens of New York City against being excluded from the nomination of the Democratic Party candidates in the coming election. In the long address written by their leaders and reprinted in Portsmouth Oracle, Pulaski - along with Lafayette, Hamilton and von Steuben - is mentioned as a revered and lamented American hero irrespective of his foreign origin. ${ }^{45} \mathrm{An}-$ other instance of using Pulaski's name and national origin for a political purpose comes from the year 1813, as an argument against the discrimination of Irish-born persons. This time he served as an example that a foreign-born person could serve America well. When Nicholas Gray, an Irish refugee, was made Inspector General of the US army during the war of 1812, an approving commentary appeared in The Albany Argus:

The history of our revolution and the important aid we derived from European officers in that contest, at once prove that the practice is not novel. Pulaski and Kosciusko were Poles; La Fayette a Frenchmen; Steuben German, and Montgomery an Irishman; and yet these men were invested with high offices, enjoyed the confidence and esteem of Washington, and received the grateful plaudits of the nation. ${ }^{46}$

In conclusion, the archival material analyzed in this essay, although not quantitatively impressive, provided new insights into the history and dynamics of Casimir Pulaski's road into the social memory of early Americans. The chronology and content of reporting Pulaski in the studied newspapers reveal two distinct phases down that road: immediate remembrance and delayed remembrance, separated by

\footnotetext{
43 The Daily Advertiser, July 11, 1796, p. 2.

44 City Gazette And Daily Advertiser, July 31, 1812, p. 3.

45 April 29, 1809, p. 2.

46 April 13, 1813, p. 3.
} 
the silent period of about fourteen years. The first stage, lasting about two years, consists mostly of factual reporting of Pulaski as a real person performing military operations. Although those news messages may not have been written with the intention to construct Pulaski as an American military hero, his characteristics and brave deeds in the dramatic historical circumstances made him a newsworthy heroic topic notwithstanding. He fitted perfectly the themes of the military hero recipe identified by Cavender and Prior in the media narratives of the $21^{\text {st }}$ century: 1) he was male; 2) his biography located him in a prominent position of a general; 3) he demonstrated a strength of purpose and 4) he represented the goals and values of the American revolutionaries. ${ }^{47}$ All these elements occurred explicitly or were implied in the reports of 1777-1779 concerning Pulaski.

The subsequent long period of silence about Pulaski in the Early Republican press cannot be interpreted as evidence of his complete disappearance from American social memory. Firstly, this may be an inaccurate impression resulting simply from what historical newspapers are extant and digitized. Secondly, it may as well be a chance absence from the press. Even so, the lack of newspaper reports on an event does not indicate that it did not occur, as pertinently observed by the sociologist Herbert Danzger. ${ }^{48}$ Doubtlessly, while Pulaski lost his news value to the American press after 1777, memories about him persisted in society via different channels, a fact confirmed by the contexts in which his name surfaced in various newspaper sections after 1793. A battleship owner, a horse-breeder, a bookseller, a poet, a college student, a group of cadets, state legislators and political activists who used Pulaski's name for the expression of their own ideas and the achievement of their specific goals - military, patriotic, ethical, commercial and artistic - would not have done so without being familiar with his biographical details and with his high reputation established during the war. How they acquired that knowledge, whether from direct past experience, from other printed sources or by word-ofmouth, remains beyond the scope of this study, but evidently American newspapers between 1779 and 1815 no longer performed the role of major remembrance sites for Pulaski. Significantly, they recirculated his name - albeit infrequently and often briefly - once the Republic was consolidated and when the Revolutionary War stopped being news and became "the first history" of the new independent nation and its founding myth. At that stage, the newspapers testify to the cultural persistence of Casimir Pulaski in American national memory. As an overseas hero of the Revolution, he remained relevant for later cultural formations and adaptable to new social needs and contexts. ${ }^{49}$

47 Gray Cavender and Sarah Prior, Constructing the Military Hero, "International Journal of Criminology and Sociology" 2013, vol. 2, pp. 469-480.

48 Quoted in Franzosi, op. cit., p. 7.

49 On mnemonic persistence and malleability, see Olick and Robbins, op. cit., p. 129. 


\title{
Kazimierz Pułaski alias Casimir Pulaski and His Memorial Trajectory in the Eighteenth-Century American Press
}

\begin{abstract}
Summary
Casimir Pulaski enjoys today the established status of a Polish-American national hero. A political refugee from his native Poland after the defeat of the Bar Confederation, he came to America in 1777, during the War of American Independence, founded the Polish Cavalry Legion, fought against the British and died in 1779 in the rank of brigadier general of the Continental Army. The present historical study in mnemonic practices is an attempt to demonstrate how American newspapers in the years 1777-1815 participated in shaping Pulaski's image of a hero in the national memory during the formative period of the United States. The quantitative and qualitative analysis of Pulaski's newspaper appearances in the study material showed that his media-enhanced road to prominence in the national memory followed a winding and fragmented course. Two phases of the process, separated by 14 years of complete absence of Pulaski from the American press, have been identified: 1) immediate remembrance by means of factual war reports characterized by "heroic" discourse, and 2) delayed remembrance in the form of dispersed information about the social uses of Pulaski's name for patriotic, political and commercial purposes. Concluding, after two years of fact-based reporting as a living military hero, Pulaski's newsworthiness declined for several years after his death. His name was subsequently recirculated in contexts pointing to the process of his myth formation in American culture as part of the foundation myth of the United States.
\end{abstract}

Key words: Casimir Pulaski, newspapers, social/national memory, mythologization, American Revolution, Early American Republic

\section{Kazimierzy Pułaski i pamięć o nim kształtowana przez prasę amerykańską XVIII wieku}

\section{Streszczenie}

Kazimierz Pułaski zajmuje dziś niekwestionowaną pozycję „,bohatera dwóch narodów" jako uczestnik antyrosyjskiej Konfederacji Barskiej w Polsce oraz generał Armii Kontynentalnej walczący i poległy w Ameryce w batalii o niepodległość Stanów Zjednoczonych. Niniejsze studium z zakresu historii praktyk mnemonicznych pokazuje wyniki badań prasy amerykańskiej okresu 1777-1815 pod kątem jej roli w kształtowaniu miejsca i wizerunku Pułaskiego, znanego w Ameryce jako Casimir Pulaski, w zbiorowej pamięci powstającego wówczas narodu 
amerykańskiego. Badania ilościowe i jakościowe wzmianek prasowych dotyczących Pułaskiego w zgromadzonym materiale wskazują na dwie fazy procesu jego upamiętniania: 1/ pamięć bezpośrednia w postaci bieżących doniesień o jego działaniach bojowych podczas trwania amerykańskiej wojny o niepodległość, utrzymanych w dyskursie heroicznym, oraz 2/ pamięć przywrócona poprzez wzmianki i informacje o pojawianiu się nazwiska Pułaskiego w różnych kontekstach społecznych; patriotycznym, politycznym, komercyjnym oraz artystycznym. Fazy te oddziela okres ok. 14 lat całkowitej nieobecności Pułaskiego na stronach ówczesnych gazet amerykańskich. Widać stąd, że Pułaski, przedstawiany za życia jako bohater wojenny, po śmierci w 1777 r. na kilkanaście lat przestał być dla prasy tematem aktualnym. Jednak treść krótkich i dłuższych informacji, w których nazwisko Pułaskiego ponownie zaczęło pojawiać się w prasie wczesnorepublikańskiej świadczy o trwającym już wówczas procesie jego mitologizacji w kulturze amerykańskiej jako elementu narodowego mitu o początkach Stanów Zjednoczonych.

Słowa kluczowe: Kazimierz Pułaski/Casimir Pulaski, prasa, pamięć społeczna/narodowa, mitologizacja; rewolucja amerykańska, Wczesna Republika amerykańska

\section{Bibliography}

\section{Primary Sources}

Early American Newspapers, Series 1, 1690-1876, Readex America's Historical Newspapers [Online]. Available at: http://0-infoweb.newsbank.com.pugwash.lib.warwick. ac.uk/

Virginia Gazettes, Williamsburg Newspapers from 1736 to 1780, Colonial Williamsburg Foundation, http://research.history.org/DigitalLibrary/va-gazettes/

\section{Secondary Sources}

Baumgartner, J., Newspapers as Historical Sources, "Philippine Quarterly of Culture and Society” 1989, vol. 9, 1989.

Bednarek M. and H. Caple, News Discourse, London 2012.

Bourguet, M-N., L. Valensi, N. Wachtel, eds., Between Memory and History, Chur, London and Paris 1990.

Allen, R.B. and R. Sieczkiewicz, How Historians use Historical Newspapers, "Proceedings of the American Society for Information Science and Technology" 2010, vol. 47. Brown, R.D., Knowledge is Power: The Diffusion of Information in Early America, 1700-1865, Oxford and New York 1989. 
Cavender G. and S. Prior, Constructing the Military Hero, "International Journal of Criminology and Sociology” 2013, vol. 2.

Clark, C.E., The Public Prints: The Newspaper in Anglo-American Culture 1665-1740, New York and Oxford 1994.

Cohen D. and R. Rosenzweig, Digital History: A Guide to Gathering, Preserving, and Presenting the Past on the Web, Philadelphia, 2005.

Cubitt, G., History and Memory, Manchester 2007.

Daszyńska, J., "Droga Pułaskiego do Savannah”, [in:] Czas Ameryki. American Era, Księga ku czci Profesora dr. hab. Krzysztofa Michałka, red. H. Parafianowicz, Białystok 2011.

Fentress J. and C. Wickham, Social Memory, Cambridge, Mass. 1992.

Fowler, R., Language in the News: Discourse and Ideology in the Press, London and New York 1991.

Franzosi, R., The Press as a Source of Socio-Historical Data: Issues in the Methodology of Data Collection from Newspapers, "Historical Methods" 1987, vol. 20 (1).

Funkenstein, A., Collective Memory and Historical Consciousness, "History and Memory" 1989 , vol. 1 (1).

Harris M. and A. Lee, eds., The Press in English Society from the Seventeenth to Nineteenth Centuries, Vancouver 1986.

Hickey, D.R., The War of 1812: A Forgotten Conflict, Bicentennial Edition, Urbana 2012. Interchange: The War of 2012, "Journal of American History" 2012, vol. 99 (2).

Kajencki, F.C., Casimir Pulaski: Cavalry Commander of the American Revolution, El Paso 2001.

Kersten, A., W sprawie badań nad początkami prasy polskiej, "Kwartalnik Historyczny" 1963, vol. 1.

Kolasa, W.M., Historiografia prasy polskiej (do 1918 roku), Kraków 2013.

Konopczyński, W., Kazimierz Pułaski; życiorys, Kraków 1931.

Krzywobłocka, B., "Prasa jako źródło historyczne”, [in:] Mieczysław Kafel, ed., Metody i techniki badawcze w prasoznawstwie, t. 3, Warszawa 1971.

Kupisz, D., A. Pytlak, eds., Kazimierz Pułaski i jego czasy w historii, literaturze, kulturze. W 270 rocznice urodzin, Radom 2016.

Lenkiewicz, A., Kazimierz Pułaski (1745-1779), Wrocław 2004.

Olick J.K. and J. Robbins, Social Memory Studies: From "Collective Memory" to the Historical Sociology of Mnemonic Practices, “Annual Review of Sociology” 1998, vol. 24.

Polasik-Wrzosek, K., Pamięć kulturowa a historiografia. Konteksty do zbadania, "Historyka” 2011, vol. XLI. 
Pytla, A., ,Mit Pułaskiego w operze francuskiej doby Rewolucji: Lodoïska Luigiego Cherubiniego i Lodoïska Rodolphe'a Kreutzera”, in: D. Kupisz, A. Pytlak, eds, Kazimierz Pułaski i jego czasy w historii, Litersturze,kulturze, Radom 2016.

Roediger, Henry L., James V. Wertsch, Creating a new discipline of memory studies, “Memory Studies" 2008, vol. 1 (1).

Stefaniak, I., ed., 40 lat Muzeum im. Kazimierza Pułaskiego w Warce. Bohater, historia i perspektywy rozwoju. Materiały z polsko-amerykańskiego sympozjum w Warce-Winiarach, 13-16 października 2007r./ Forty years of the Casimir Pulaski Mut seum in Warka. The hero, history and perspectives for development. Papers from the Polish-American symposium in Warka-Winiary, October, 13-16, Warka 2007.

Stefaniak, I., K. Kucharski, eds., Kazimierz Pułaski w 230. rocznice śmierci. Materiaty z sesji naukowej zorganizowanej 7 grudnia 2009 r. w Muzeum Niepodleglości w Warszawie, Warka 2011.

Szpociński, A., Nośniki pamięci, miejsca pamięci, "Sensus Historiae” 2014, vol. 17 (4).

Szymanski, L., Casimir Pułaski: A Hero of the American Revolution, New York 1979/1994.

Tallentire, J., Strategies of Memory: History, Social Memory, and the Community, "Histoire Sociale/Social History" 2001, vol. 34(67).

Thelen, D., Memory and American History, "Journal of American History" 1989, vol. 75 (4). 